\title{
Marka Deneyiminin Güven, Tatmin ve Bağlılığa Etkisi
}

\author{
Kamile Çetin
}

\begin{abstract}
Öz
Günümüzün yoğun rekabet pazarında tüketici ve markalar ile yaşamış oldukları deneyimler önemli bir kavram haline dönüşmüş, markalar ile yapılan her olumlu iletişim güven, tatmin ve bunun sonucunda da sektör için olumlu sonuçları doğurmuştur. Bunun sonucunda ise markalara karşı oluşan bağılıı gerçekleşmiştir. Çalışmada; tüketicilerin markalar ile olan deneyimlerinin, marka güveni, bağlılığı ve tatmini ile olan ilişkisini belirleyebilmek amaçlanmıştır. Oluşturulan hipotezleri test etmek üzere 252 kişiye elektronik ortamda toplanan veriler doğrultusunda, doğrusal regresyon analizi, tek yönlü varyans analizi (ANOVA) ve bağımsız t-testi uygulanmıştır. Çalışmada marka deneyiminin marka bağlılığı, güveni ve tatmini üzerinde anlamlı etkisinin olduğu sonucuna varılmıştır. Demografik değişkenlerden meslek ve marka deneyimi arasında da istatistiksel olarak anlamlı ilişki olduğu belirlenmiştir. Bununla beraber; marka deneyimi ile eğitim, gelir düzeyi, yaş ve medeni durum arasında anlamlı ilişkinin olmadığı yapılan araştırma sonucunda ortaya çıkmıştır.
\end{abstract}

Anahtar Kelimeler: Marka deneyimi, marka bağlılığı, marka güveni, marka tatmini

\section{Brand Experience Effects On Trust, Satisfaction And Context}

\begin{abstract}
Consumers and their brand experiences have become an important concept in today's intensive competition in the market and every positive communication established with brands have resulted in trust, satisfaction and therefore favorable outcomes for the sector. As a result of this, brand loyalty has been realized. In this study; it is aimed to determine the relationship between consumers' brand experiences with brand trust, loyalty and satisfaction. In order to test the hypotheses, developed, linear regression analysis, one-way analysis of variance (ANOVA) and independent $t$-test were applied to data collected from 252 participants in electronic media. The study concluded that the brand experience had a significant effect on brand loyalty, trust and satisfaction. It was also determined that there is a statistically significant relationship between occupation, one of demographic variables, and brand experience. However, it was revealed that there is no statistically significant relationship between brand experience and education, income level, age and marital status as a result of this study.
\end{abstract}

Keywords: Brand experience, brand loyalty, brand trust, brand satisfaction

${ }^{1}$ Necmettin Erbakan Üniversitesi, Eğitim Bilimleri Enstitüsü, Özel Eğitim Tezsiz Yüksek Lisans Programı Mezunu, kamilecetin77@gmail.com 


\section{Giriş}

Geçmişte tüketici pazarlamasında sadakat, tüketici memnuniyeti ile eş değer tutulmuştur. Markalar tüketicilerini tatmin ederse, onların kendilerine bağlanacaklarını düşünmektelerdi. Bundan dolayı daha iyi ve kaliteli bir ürün ya da hizmet, kalite üzerine kurulmuştur. Günümüzde memnuniyet ve kalite halen beklenilen bir koşuldur. Ancak, kıyasıya rekabetle birlikte tüketicilerin kendilerini memnun eden markalara sadık kalamadıkları görülmektedir. Bir markanın müşterisi tarafından fiyat unsuru gözetmeksizin tekrar tercih edilip edilmediği ya da tercih edilme sıklığı, markanın müşterisinin tercih listesinde kaçıncı sırada olduğu, markanın bağılıığı hakkında fikir vermektedir (Sakınç 2014: 61).

Markalara karşı oluşturulan güven, değer için önemlidir. Tüketicilere ürün ya da hizmeti sadece sağlamakla yetinmemek, aynı zamanda da tüketicilerin farklı tatminlerde buluşmalarını sağlamak gerekmektedir. Bunun yolunun ise tüketicilerin demografik faktörlerini de göz önünde bulundurarak onların ne istediklerini keşfetmekten geçtiği bilinmelidir. Marka tercihlerinde, yaş, cinsiyet, medeni hal, gelir, eğitim ve meslek gibi farklılıkların etkili olduğu ve yaşam tarzının, elle tutulamayan hislere, duyulara hitap eden, güven, memnuniyet, müşteri değeri ve bağlılığı gibi özellikler maddi özelliklerin yerine geçtiği (Güven 2009: 11) unutulmamalıdır. Aynı tatmin edici hisleri tekrardan yaşamak için deneyimlemek gereklidir. Tekrar eden davranışlar, alıșkanlıklara dönüșür ve onlardan vazgeçmek zorlaşır. Bunun olumlu sonucu ise markalara karşı oluşan bağlıııktır. Tüketicilerin markalar ile kullanım esnasında yaşamış oldukları deneyim önemlidir. Sektörde markaların rakip markalarla rekabet edile bilinirliliğini sürdürebilme çabalarında, tüketici ve markalar ile ilgili olumlu bir deneyim yaratabilmeleri gerekmektedir. Sektör tüketicilerine markaları ile tatmin yaşatabilir ve bunun sonucunda da markalarına güven oluşturabilirlerse bağlı tüketiciler yaratılabilecek ve bağlılıkların sürekliliği sağlanarak markaların tercih edilebilirliğini sağlayabileceklerdir.

\section{KURAMSAL ÇERÇEVE VE LITERATÜR TARAMASI}

\section{Marka Deneyimi}

"Bir mal ya da hizmeti kullanan tüketiciler, o mal ya da hizmetten daha üst düzeyde fayda sağlamak için, onda ne gibi özellik ve işlevlerin bulunması gerektiğini, deneyimlerine dayanarak üreticiden daha iyi bilebilirler" (Ismailoğlu 2013: 44).

"Deneyim, müşteri katılımı ve çevresel ilișkiden olan" (Joseph \& Gilmore 1998) "markanın tasarımı, kimliği, ambalajı, iletişimi gibi uyaranlar ile oluşan" (Brakus, Schmitt, \& Zarantonello 2009) tüketiciyi sosyal, fiziksel ve duygusal açılardan etkileyen, "sadece müşterinin zihninde var olması sebebiyle kişisel olan" (Johnston \& Kong 2011) ekonomik çıktılar (Joseph \& Gilmore 1998) şeklinde oluşan bir kavram olarak görülmektedir.

Genel bir ifadeyle deneyim; "ürün deneyimleri, hizmet deneyimleri, estetik deneyimler, alış- veriş deneyimleri, marka deneyimleri ve tüketici deneyimleri" (Şahin 2011: 42) olmak üzere farklı biçimlerde karşımıza çıkmaktadır. Markalar ve tüketiciler arasında duygusal olarak yaratılan bağ tüketicilerde olumlu bir takım deneyimler yaşatarak markalara karlı oluşan bağlılığı sağlayacaktır. Tüketiciler herhangi bir markaya bağlanacakları zaman öncelikle markalarda, bekledikleri ölçütlerin, hedeflerin ve tutarlııkların o ürün ya da hizmette olmasını tercih ederler. Markaların onlara sağlayacakları fayda, hedef ve beklentilerdeki tutarlılıklarında yaşamış oldukları deneyimler, ona karşı güven oluşturacaktır. Markayı tanıdıkça ve tatmin oldukça, ürün ya da hizmete karşı oluşan güven ve tatmin duygusu artacaktır. 
Deneyim bir bütündür. Bir tüketicinin ürün ya da hizmeti, satın alım öncesinde etkili olan kişisel faktörler (cinsiyet, yaş, eğitim, vb), ekonomik faktörler (gelir vb.), psikolojik faktörler (kişilik, tutum ve inançlar vb.) ve sosyolojik faktörler satınalma sürecinde etkili olurken, alışveriş ve tüketim sonrasına kadar geçen süreç zincirin her aşamasından elde ettiği değerin toplamı deneyim olarak karşımıza çıkmaktadır.

Satınalma davranışına yönelecek olan tüketici, marka ile olan temasına geçtiği andan itibaren deneyimlemeye başlar. "Tüm bu süreç yaşanırken müşteriyi memnun etmek, güveni sağlamak ve onun tekrardan satın alma kararına yöneltebilmek için "müşterinin beklenti ve isteklerinin çok iyi anlaşılması gereklidir" (Eraslan2006:138). Tüketici marka deneyimini çeşitli şekillerde "duyumsal (görme, işitme, koklama, tat ve dokunma duyularıla), duyguları ile markaya tepki vererek ve sosyal ortamlarda markanın etkilerine katılarak yaşar" (Barış 2004: 21).

Deneyimsel tüketim kişilerin ihtiyaçlarının karşılanmasında önemlidir. Bir kimsenin herhangi bir şekilde, bir markanın düzenlemiş olduğu bir faaliyete katılması, reklamına maruz kalması, web sayfasını ziyaret etmesi, o markayı kullanan birinden markaya yönelik bilgiler alması, o markanın logosunu görmesi veya ismini duyması vb. tüm olaylar, o marka ile deneyim yaşanması ile sonuçlanmaktadır (Başer 2011: 88). "Müşteriler, markayı çoğunlukla daha önceden kullanmış ve "markanın özellikleri, inanılırlığı konusunu sıklıkla iyi bir şekilde değerlendirmiştir" (Doyle 2003: 398).

Marka deneyimi ile ilgili yapılan bazı çalışmalarda; Öztürkcan \& Kervenonel (2008) yaptığı çalışmasında bireyle etkileşimde canlı bir marka deneyimi yaşanabilirse, ait olduğu markayı tüketicinin tekrar tercih edeceğini ve Batı'nın çalışmasında (2009) insanların artık alışveriş tercihlerini daha önce edindikleri deneyimler doğrultusunda yaptıkları görüşü üzerine yapılanmış bir tüketim yaklaşımının olduğu görüşünü savunmuştur. Tüketicilerin marka ile temas etmiş olduğu her alan, her faktör ve deneyim markayı tekrardan tercih etmesinde etkilidir. Çünkü tüketicilerin zihninde kalan sadece markalar ile olan deneyimdir. "Satın alma davranışları açısından üniversite öğrencileri arasında marka bağımlılığının önemi" adlı Türkay (2011: 75) ın yaptığı çalışma incelendiğinde üniversite öğrencilerinin cep telefonu satınalma tercihlerini incelenmiş olup, çalışmanın sonucunda öğrencilerin daha önceden deneyimlediği cep telefonu markalarına karşı güvensizlik ve tatminsizliğin oluştuğu sonucuna varılmıştır. Kohen (2015)'in yaptığı çalışmasında ise "Türkiye çağrı merkezi müşteri deneyimi" araştırmasında çağrı merkezi ile oluşan deneyimden memnun kalan tüketici/müşteriler, markaya karşı olan bağlılıklarını sürdürmeye devam ettirmekte oldukları ve araştırmada her iki kişiden birinin (\%53) markayı başkalarına tavsiye edebileceğini belirtirken, markaya bağlılığını kaybedenlerin yüzde 81 'i, bunda çağrı merkezi deneyiminin etkili olduğunu belirtmişlerdir. Ve yine (Alemdar: 2010)'ın araştırmasında da, duygusal markalamada ürün ve fiyata bağlı yaratılan değerin yanında, marka deneyimleri ile de yaratılabileceği sonucuna varılmıştır. Marka deneyiminin marka bileşimleri ve tüketicilerin demografik özellikleri ile önemli bir etkileşimde olduğu unutulmamalıdır.

\section{Marka Bağlılığı ve Deneyimi}

Tüketicilerin aynı markaya karşı tekrar eden ürün ya da hizmetleri satın alma isteği markaya ilişkin psikolojik ya da demografik nedenlere dayanmaktadır. Marka kendini tarif etmek, imaj oluşturmak ve bir bakıma da kimlik kazanmaktır. Marka bağlılığı "müşterinin daha önceden satın aldığı markayı bir memnuniyet açıklaması olarak tekrar satın alması olarak tanımlanabilir" (Ar 2004: 90). Marka bağlılığının işletmeler için önemli sonuçları bulunmaktadır. Markalara karşı oluşan bağlıııkta, ürünü ya da hizmetin bir kere satınalması değil, sürekli satınalınma sağlanarak her zaman tüketicilerde olumlu fikirlerin oluşmasını sağlamalıdır. Markaya karşı bağlılığı yüksek olan tüketiciler, diğer markaları zorunlu olmadıkça satın almaktan 
kaçınırlar. Her bir marka, farklı bir tüketici tanınırlığı olușturur. Markalar tüketicilerine "değer katan bir vaat sunabildikleri ve bunu etkili bir şekilde yerine getirebildikleri takdirde marka bağlılığı (sadakati) oluşturabilmektedirler" (Eraslan 2006: 138). Bundan dolayıdır ki üretilen hizmet ya da markanın, üreticilerin kendi gözleri ile değil de onu tercih edenin gözü ile görüp tüketicinin talep ettiği özelliklere uygun olan ürünlerin oluşturulması ve deneyimlerin olumlu olması amaçlanmalıdır. Çünkü "temel bir ihtiyacı karşılayan bir ürün ve onu temsil eden isim yani marka, insan zihninde yer ettikten sonra onu yerinden etmek oldukça güçtür" (ilgüner 2006: 69).

Literatürde marka bağlılığını etkileyen faktörler incelendiğinde; markaların ünü, markalardan beklentiler, markaların tüketici zihninde oluşturmuş oldukları yeterlilikler, marka beğenisi, markalarla yaşanılan tatmin duygusu, güven, marka tanınırlığı ve marka deneyimi tercihlerinde etkili olmaktadır. Marka tanınırlığı, tüketicinin değişik koşullar altında hatırlama ya da tekrar tanıma yeteneğini ifade eder (Yüksel \& Yüksel 2005: 87). Fakat marka tercihinde yeterli bir güç oluşturmaz. Marka tercihinde; tüketici, markalar aracılığı ile ürün ya da hizmete dikkat çekmektedir. Bu aşama tüketicilerin marka ile ilgili deneyimler yaşadığı ve sonrasında ise bağlılıkların oluşacağı aşamadır. Tüketici aracılardan, mağazalardan, internet ve sipariş yolu ile ürüne ulaşmak için çaba sarf eder. Markalarda deneyim oluşturulması ve doğru kullanılması bağlılık için önemlidir. Tüketicinin geçmişte aynı ürün ya hizmeti kullanması sonucu edindiği tecrübeler markalar ile yaşamış olduğu deneyimler arttıkça markayı daha iyi anlayacak ve bağlılığı artacaktır. Markalar ile kurulacak olan duygusal bağlar ve tüketicinin ihtiyaçlarının karşılanması gelecekte de o marka ya da ürünlerin tercih edilmesini sağlayacaktır. Bundan dolayıdır ki markalar ile doğru deneyimlerin oluşturulması markalar için önemlidir.
Literatürde, "ambalajlı dondurma sektöründe marka bağlılığına etki eden faktörler" incelendiğinde, marka güveni ve marka tatmininin "hem tutumsal sadakate hem de davranışsal sadakate yol açtığı ve kişide olumlu duygular geliştiğinde tekrar eden tüketimlerin olacağı" (Büyük, Erciş, \& Türk 2014: 27) sonucuna ulaşılmıştır. Bir diğer çalışmada da, hazır giyim ürünlerini satın almak üzere internetteki alışveriş sitelerini tercih eden Doğu Anadolu bölgesindeki tüketiciler üzerinde bir çalışma yapılmıştır. Bulgular neticesinde ise müşteri deneyimi ile müşteri bağlılığı arasında bir ilişkinin olduğu, marka tatmini yaşamış kişilerin bağlılıklarının daha kuvvetli oluşacağı sonucuna varılmıştır. (Akyüz 2014: 97).

\section{Marka Tatmini ve Deneyim}

Tatmin kavramı, pazarlama alanında en temel kavramlardan biri olarak görülmektedir. Literatür incelendiğinde, tüketicinin "bir mal ya da hizmetten tatmin olması; o mal ya da hizmetin fiili performansı ile tüketim öncesinde o mal ya da hizmetten umduğu performansı eşit ya da üstün olması demektir" (İsmailoğlu 2013: 28). Müşteri tatmini birçok tanımla ifade edilse de "sonuçta bireyin (müşterinin) algı ve değerlendirme ve deneyimlerine dayanan bir olgudur" (Boyuk \& Küçük 2007: 286). Bununla birlikte "marka tatmini, marka bağlılığının gelişiminde rol oynadığı bilinmektedir" (Erge 2011: 53). Tüketicilerin kendi istek ve beklentileri doğrultusunda markaların sahip olduğu nitelikler arasındaki yakınlığın ya da uzaklığın bir sonucu olarak ortaya çıkacak ve "tüketici markayı kullandıktan sonra, marka verdiği sözleri tutarsa tüketicinin tatmini ve markaya duyduğu güven artacaktır" (Devrani Korkmaz 2009: 412).

Marka tatmininde unutulmaması gereken, tüketicilerin alacakları ürün ya da hizmetin önceden almış oldukları ürün ya da hizmetler karşılaştırılarak almasıdır. "Her alınan hizmet ya da mal bir sonraki hizmet için temel oluşturmaktadır" (Başer 2011: 22). Tatmin olmuş tüketiciler marka hakkında yaşamış 
oldukları olumlu deneyimler sonucunda, olumlu söz ve duygular ile çevrelerine markaları daha iyi tanıtacak ve dolaylı olarak da farklı tüketicilerin de markalara yönlenmesine yardımcı olması sağlanacaktır. Dolayısıyla bu alınan hizmet ya da mallar deneyim sağlanarak bağlı müşterilere dönüşecektir. "Bu doğrultuda tatminin, güven ve bağlııı aracılığıyla satın alma niyetini ve sadakati etkilediğini ortaya koymaktadır" (Özdemir \& Koçak 2012: 134). "Müşteri bağlılığının, müşteri tatminiyle, müşteri tatmininin de müşteri memnuniyetinin sonucunda gerçekleștiği ve marka deneyimlerinin oluştuğu belirtilir. Bu bakımdan bağlılık "doğrudan tatmine dayandırılmakta ve ilişkilendirilmektedir" (Kılıç 1998: 40). Araştırmalar, "bir markanın ilk kez denenmesinden sonra duyulan memnuniyetin, yeni bir satın alma kararında, diğer alternatifler değerlendirilmeden, o markanın tercih edilmesine neden olduğunu göstermektedir" (Devrani Korkmaz 2009: 418).

\section{Marka Güveni ve Deneyim}

Markalar ile olan güven duygusu marka ile olan iletişimde çok önemlidir. Tüketiciler güvenmediği bir firmanın veya markanın ürünlerini satın almak istememektedirler. Güven; "bir markayı satın alma yönündeki niyetten önce markaya inanmaktır" (Eren \& Erge 2012: 4456) şeklinde tanımlanabilir. Markaya karşı oluşan güven duygusu, kişilerin geçmişte markalar ya da ürünler ile yaşamış oldukları deneyimler doğrultusunda şekillenir. "Güven duyulan bir marka olmak, bağlı müşterileri beraberinde getireceğinden sürdürülebilir rekabetçi avantaj açısından oldukça önemlidir" (Çabuk \& Orel 2008: 104). Tüketicilerin bireysel özellikleri ile markanın güven imajını değerlendirme sürecinde, marka ile yaşamış oldukları deneyimler oldukça önemlidir. Bu değerlendirmelerde, tüketim sonucu elde ettikleri deneyim, kullanım ya da memnuniyetle ilgili direkt ya da ağızdan ağza iletişim, markanın güvenilirliği ya da tanıtım yoluyla elde edilen dolaylı özelliklerden etkilenmektedir. "Tüketim sonucu elde edilen deneyimler, güven kaynağı olarak daha fazla önem kazanır" (Onur 2011: 78). Çeşitli markalara karşı oluşturulan güven, iki farklı süreç sonucunda oluşabilmektedir. Bu süreçler; "güvenilirlik odaklı güven ve memnuniyet odaklı güven'dir. Güvenilirlik odaklı güven oluşumu, markanın imajı doğrultusunda geçmişten günümüze değin oluşturmuş olduğu izlenimler doğrultusunda şekillenmektedir. Memnuniyet odaklı güven ise müşterinin ilgili markanın bir ürününden ya da hizmetinden memnun kalması doğrultusunda şekillenmektedir" (Doğan \& Özkara 2013: 8).

Tüketiciler markalar ile deneyimler sonucunda güvenmiş oldukları firmalardan satın alma faaliyetlerinde bulunurlar. Marka güveni tüketicilerin geçmiş deneyimleri ile zamanla gelişir. Bu güveni elde ettikten sonra ise, "tüketiciler güven duydukları markanın her şart ve her koşulda aynı davranacağını ve kendilerini memnun edeceğini düşünmektedirler" (Şahin 2011: 48). Şahin, (2011: 42) yapmış olduğu "Marka ve iletişimin Marka Sadakatine Etkisi” adlı çalışmasında, arabalar, cep telefonları ve spor ayakkabılar bağlamında deneyimin marka güvenini olumlu yönde etkilediği, tüketici ile marka arasında ilişkide güven duygusuna marka ile olan tecrübe sonucunda ulaşıldığı kanısına varılmış ve marka bağlııı̆ıının temelinde tüketicilerin o marka ile olan deneyimleri ve güveninin yer aldığı belirtilmiş. Eğer markaya karşı tüketim deneyimleri olumluysa, güven yaratacağı, bunun sonucunda da markaya karşı oluşan güvenin etkisiyle bağlılık davranışının gelișeceği Türkay, (2011) yapılan çalışmasında belirlenmiştir.

Ay, Özbey, \& Yıldız (2012: 10) ın yapmış oldukları çalışmada, futbol takımlarında tüketici temelli marka değerini incelemiş, marka güveninin tutumsal bağlılık üzerinde olumlu yönde etkisi olduğunu ileri sürmüş "marka deneyiminden elde edilen sürekli yenilenen tatmin düzeylerinin de tüketicilerde markalara karşı bağlılık geliştireceği belirtilmiştir". Akkuş, Yapraklı, \& Akkuş, (2014:423 ) online alışveriş yapan bireylerin yaşadığı deneyimlerin güveni 
etkileyip etkilemediğini Erzurum ilinde yaşanan 440 kişi üzerinde çalışmış ve sonucunda ise satın alma kararını etkileyen müşterinin tercihlerinin belirlenmesinde deneyimin önemli olduğunu bilişsel deneyim ve duyuşsal deneyimsel durumun online güven üzerinde anlamlı ve pozitif etkiye sahip olduğu sonucuna ulaşılmıştır. Özellikle de 3140 yaş grubundaki tüketicilerin markaya güvenlerinin daha çok olduğu görülmüştür. Gürbüz \& Doğan,(2013:239-258).

\section{MARKA DENEYIMININ GÜVEN, TATMIN VE BAĞLILIĞA ETKISI}

\section{Araștırmanın Amacı}

Araştırmanın genel amacı; bir ürün ya da marka seçiminde tüketicilerin markalar ile yaşamış oldukları deneyimlerinin, tatmin, bağlılılık, güven ve sosyo- demografik değişkenler ile olan ilişkilerini analiz etmek amaçlanmıştır. Bu çalışma nicel bir metodolojiyi benimsemiştir. Bilgi toplama aracı olarak online anketler katılımcılara uygulanmıştır. Veriler çıkarımsal istatistiklerle yorumlanmıştır.

\section{Araştırmanın Önemi}

$\mathrm{Bu}$ araştırmayla tüketicilerin markalara karşı oluşturdukları satın alma davranışlarında marka deneyim algılarının oluşmasında (bağlılık, tatmin ve güven) değişkenlerinin etkileri ortaya çıkarılmıştır. Ardından tüketicilerin özellikle demografik özelliklerinin marka deneyim algılarındaki etkileri ortaya konulmuştur.

\section{Araștırmanın Hipotezleri}

Araştırmada tüketicilerin marka deneyimi algısının, marka güveni, tatmini ve marka bağlılığı üzerinde etkili olduğunu varsaymaktadır. Ayrıca marka deneyimlerinin algılanmasında tüketicilerin sosyo demografik özelliklerine göre, aralarında anlamlı farklılıkların olduğu düşünülmektedir.
$\mathbf{H}_{1}$ Tüketicilerin marka deneyimi algısının, marka tatmini üzerinde istatiksel olarak anlamlı bir etkisi vardır.

$\mathbf{H}_{\mathbf{2}}$ : Tüketicilerin marka deneyimi algısının, marka güveni üzerinde istatiksel olarak anlamlı bir etkisi vardır.

$\mathbf{H}_{3}$ : Tüketicilerin marka deneyimi algısının, marka bağlılığı üzerinde istatiksel olarak anlamlı bir etkisi vardır.

$\mathrm{H}_{4}$ : Tüketicilerin cinsiyetine göre marka deneyimleri üzerinde istatistiksel olarak anlamlı farklıııklar vardır.

$\mathbf{H}_{5}$ : Tüketicilerin mesleklerine göre marka deneyimleri üzerinde istatistiksel olarak anlamlı farklıııklar vardır.

$\mathbf{H}_{6}$ : Tüketicilerin eğitim düzeyine göre marka deneyimleri üzerinde istatistiksel olarak anlamlı farklıııklar vardır.

$\mathbf{H}_{7}$ : Tüketicilerin yaşlarına göre marka deneyimleri üzerinde istatistiksel olarak anlamlı farklııılar vardır.

$\mathbf{H}_{8}$ : Tüketicilerin aylık kişisel gelirlerine göre marka deneyimleri üzerinde istatistiksel olarak anlamlı farklııklar vardır.

$\mathbf{H}_{9}$ : Tüketicilerin medeni durumlarına göre marka deneyimleri üzerinde istatistiksel olarak anlamlı farklııklar vardır.

\section{Araștırmanın Kısıtlılıkları}

- Anketle toplanan verilerin güvenilirliği ve geçerliliği, veri toplamada kullanılan bu tekniğin özellikleri ile sınırlıdır.

- Araştırma verilerinin sadece online anket yöntemi ile toplanılmış olması, mülakat, gözlem gibi tekniklerin kullanılmayışı çalışmanın bir diğer sınırlılığını oluşturmaktadır.

- Karşılaşılan bir diğer kısıtlılık ise marka deneyiminin (güven ve marka bağlılığı ve tatmin) ile ilişkilerini inceleyen ve yapılan yerli çalışmaların yetersizliğidir.

- Yapılan çalışmanın dayanıklı tüketim malları arasında sayılan hazır giyim ürünlerinden sadece bir örnek (LC 
Waikiki) markası referans alarak soruları yanıtlamışlardır.

- Anket verilerinde demografik özelliklerden cinsiyet incelendiğinde kadın katılımcıların erkek katılımcılardan dafa fazla ankete katılımın olması bir kısıtlılık olarak görülebilir.

\section{Araştırmada Kullanılan Yöntem}

Çalışmanın bu bölümünde; araştırmanın dayandığı model ve hipotezler, anket formunun hazırlanması, örnekleme yöntemi, verilerin toplanması ve verilerin analizi hakkındaki bilgilere yer verilmektedir.

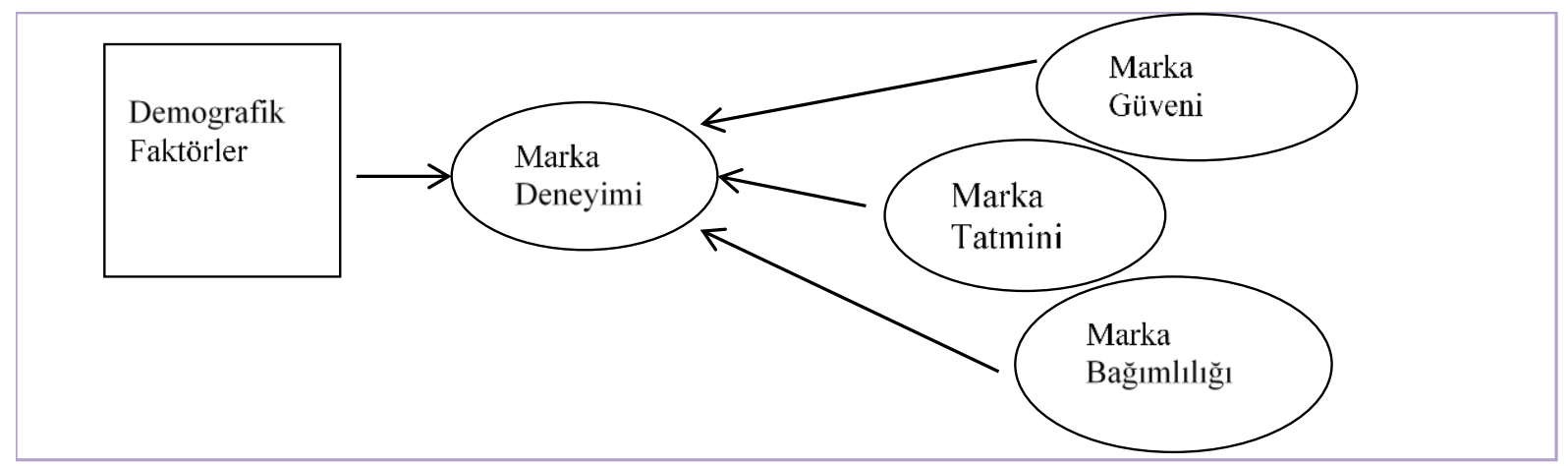

Şekil 1: Araştırmanın Modeli

\subsection{Araştırmanın Evreni ve Örneklemi}

Araştırmada tüketicilere ulaşmanın son yıllarda kullanılan en etkili ve verimli yolunun internet olduğu düşünülmüştür. Web siteleri üzerinden yapılan ve herkesin erişimine açık olan elektronik ortamdaki anketlerde akademik çalışmaların veri toplanılması ve analiz aşamasında daha kısa sürede, istenen anketlerin çok ucuza mal edilebileceği düşünülmüş, kısa bir sürede veri toplamak amacı ile markalar ile deneyim yaşamış tüketicilere uygulanmıştır. Online anket sisteminin eksik olan yanlarının olduğu da bilinmektedir. "Her soru tipine uygulanamaması, soru sayısının sınırlı olması, e-posta ile erişilen katılımcı sayısının sınırlı olması, raporlama ve saklama koşullarının güçlük oluşturması" (Kıncal, 2015, 725) gibi kısıtlı yönleri bulunmaktadır.

Bu bağlamda araştırmanın örneklem çerçevesi 252 tüketici online anket uygulanmış ve cevaplandırılmaları istenmiştir.

\subsection{Veri Toplama Aracının Geliștirilmesi}

Araştırma için yapılmış olan anket daha önceden yapılmış olan araștırmalardan derlenmiştir. Marka tatmini ile ilgili ölçek sorularında (Oliver R. L., 1997, s. 460-469), marka deneyimi ile ilgili sorularında (Brakus, Schmitt, \& Zarantonello, 2009)dan, marka güveni ile ilgili sorularda (Ballester, Delgado, \& Aleman, 2005) tarafından yapılan çalışmalar uyarlanarak, (Başer, 2011) in kaynak olarak kullandığı"Tüketicilerin Marka Deneyimi Algısının Marka Güveni, Tatmini, Sadakati üzerine etkisi ve Bir Araştırma" doktora tezinde kullanılmıştır.

Anket formu tüketici katılımına yönelik iki soru, marka deneyimlerine yönelik oniki soru, marka tatminine yönelik altı soru, marka güvenini belirlemeye yönelik sekiz soru, marka bağılıı̆̆ını ölçmeye yönelik dokuz soru, ifadede kullanılmıştır. Anket formunda tüketicilerin demografik düzeylerini belirlemeye yönelik altı soru sorulmuştur.

Anket formu hazırlandıktan sonra form ve online anket kişilere gönderilmiştir. Son olarak anket formunun içeriğinin ve anketin anlaşılabilirliğinin ölçülebilmesi için; anketler araştırmanın örnek kütlesine uygulanmadan 
online- anket yoluyla seçilen 25 kişiye uygulanmıştır. Yapılan bu ön test sonucu olarak anket üzerinde gerekli düzenlemeler yapılmış ve ankete son şekli verilmiştir. Veriler SPSS 20 paket programı kullanılarak analize tabi tutulmuştur.

\subsection{Araștırmaya Konu Olan Markanın Seçimi}

Çalışmada; ürün ya da marka seçiminde tüketim sektörü dikkate alınarak "LCWaikiki”bir giyim markası olarak seçilmiştir. LCWaikiki markası 1988 yılında temelleri atılarak 2017 yılına kadar devamlılı̆ı̆ı ve piyasada tutunmayı başarabilmiştir. "İyi Giyinmek Herkesin Hakkı" felsefesi ile 36 ülkede 769 mağazada uygun fiyata ve kalitede ürünler sunmuștur." (http://corporate.Icwaikiki.com/hakkimizda) 'LC Waikiki, hedef pazarı olan orta ve üst gelir grubuna yönelik olarak, Türkiye pazarının müşteri ihtiyaçlarını doğru olarak tespit etmiş ve bayan, erkek, bebek/ çocuk/ genç giyimi üzerine her türlü hazır giyim ürünlerini başarıyla üretmekte ve satışını gerçekleştirmektedir'(Inal, 2011). Rekabetin yoğun olarak yaşandığı pazarda ulusal ve uluslararası alanda hazır giyim sektöründe tüketiciler tarafından yoğun olarak markanın tercih edildiği düşünülmektedir.

\subsection{Verilerin Çözümlenmesi}

Uygulanan ölçekten elde edilen veriler değerlendirilerek yorumlanmıştır. Marka deneyiminin, bağlılık, tutum, güven ve demografik değişkenler değerlendirilerek toplanan verilerin tablolaştırılması yoluna gidilmiş ve bu tablolar yorumlanmıştır. Araştırma çerçevesinde uygulanan ankete ait veriler SPSS 20 paket programında incelenmiş ve elde edilen bilgiler çözümlenmiștir. Verilerin analizinde; $t$ - testi ve tek yönlü varyans analizi (ANOVA), post-hoc testlerinden Tukey HSD tekniği, regresyon analizi, Cronbach Alpha yöntemi ve faktör analizi kullanılmıştır.

\section{Araștırmanin Bulguları Ve Değerlendirilmesi}

Çalışmanın başında da belirtildiği gibi araștırmanın genel bir ürün ya da marka seçiminde tüketicilerin markalar ile yaşamış oldukları deneyimlerinin, marka tatminine, bağlılığına, güvenine ve marka deneyiminin sosyo- demografik değişkenler ile olan ilişkisini belirlenmesidir. Bu amaca yönelik belirlenen problem ve alt problemler ile öne sürülen hipotezler, yapılan çalışmalar doğrultusunda netlik kazanmıștır. "Kavram olarak güvenirlik, bir veriyi toplama tekniği ya da aracı ile aynı özelliğe dönük olarak aynı varlıklar üzerinde yapılan uygulama sonuçlarının birbirine yakın ya da birbiri ile tutarlı olma özelliğidir"(Kıncal,2015). Katılımcılara uygulanan ölçeğin güvenirliği hesaplanmış ve Alpha katsayısı 0,874 olarak bulunmuştur. $0,874 \quad>0,5$ olduğundan uygulanan tutum ölçeğinin güvenilir sonuçlar verdiğini ve sonuçlardan doğru yaklaşımlar çıkarıldığı belirtilir. Bu değer güvenilirlik analizinde alt sınır olarak kabul edilen 0,70 değerinden oldukça yüksektir.

Değişkenler arasındaki ilişkileri incelemek ve daha az sayıdaki değişkenlere ulaşabilmek adına çalışmalara faktör analizi uygulanmaktadır. Bu çalışmada mevcut literatürden alınan (Başer 2011) ölçeğinde 35 ifadeden oluşan bu yargıların araștırma modelindeki yapılara benzer bir faktör yapısında olup olmadıklarının ortaya çıkartılması amacıyla da faktör analizi uygulanması uygunlanmıştır. Araştırmada kullanılan ölçeklerin faktör yapılarını oluşturmak üzere, doğrulatıcı faktör analizi analizi yöntemi ve Varimax rotasyonu kullanılmış, keşfedici faktör analizi uygulanmıștır. Değișkenler arasındaki anlamlı korelasyonların düzeyini belirleyebilmek için KMO (Kaiser-Meyer-Olkin) yapılmıştır. Değişkenler arasında oluşan korelasyon azaldıkça faktör analizi sonuçlarına karşı oluşan güvende de azalma olacaktır. "Bu oranın .70 ' e eşit veya bu orandan büyük olması beklenir" (Hair ve diğerleri, 1998).

(Başer, 2011) in yapmış olduğu KMO (KaiserMeyer-Olkin) testi sonucunda, KMO değeri $(, 881)$ olarak bulunmuştur. Bu değer 
örneklem büyüklüğünün faktör analizi için uygun olduğunu göstermektedir. Bartlett küresellik testi ana kütledeki değișkenlerin birbiriyle ilişkili olup olmadığı anlamak için Bartlett test sonucunda yaklaşık ki kare değeri $(4530,389)$ anlamlılık ise $(0,000)$ olarak bulunmuştur. Bu sebeple, araştırmadaki örnek büyüklüğü yeterlidir. $P$ (olasılık) $=0,000$ $<0,01$ olduğundan dolayı bu koşullar altında faktör analizinin kullanılmasının uygunluğu ortaya çıkmıştır.
Faktör analizi sonucunda, toplam varyansın \% 61 açıklayan 3 adet bağımsız faktör elde edilmiştir. Bu faktör analizi sonucunda elde edilen istatistikler Tablo 2'de verilmiştir.

Tabloda, birinci faktörünün toplam varyansın \%21,989'unu, ikinci faktörünün toplam varyansın \%19,672'ını, üçüncü faktörünün toplam varyansın \%19,515'sını, marka deneyiminde açıkladığı görülmektedir. Marka sadakati ve marka güveni ölçeğinde keşfedici faktör analizi kullanılmış ve bir faktör altında analizler toplanmıştır.

Tablo 2: Marka Deneyimi Ölçeğine Yönelik Değișkenler İçin Uygulanan Faktör Analizi Sonucu

\begin{tabular}{|c|c|c|c|c|c|c|}
\hline \multicolumn{2}{|c|}{ Bileşenler (Faktörler) } & \multicolumn{3}{|c|}{ Başlangıç Özdeğeri } & \multicolumn{2}{|c|}{$\begin{array}{c}\text { Döndürülmüş Faktör Yüklerinin } \\
\text { Karelerinin Toplamı }\end{array}$} \\
\hline Toplam & $\begin{array}{l}\text { \% Varyansın } \\
\text { Yüzdesi }\end{array}$ & $\begin{array}{l}\text { Kümülatif } \\
\text { Varyans \% }\end{array}$ & \multicolumn{2}{|c|}{ Toplam } & $\begin{array}{l}\text { \% Varyansın } \\
\text { Yüzdesi }\end{array}$ & $\begin{array}{l}\text { Kümülatif } \\
\text { Varyans \% }\end{array}$ \\
\hline 1 & 5,130 & 42,753 & 42,753 & 2,69 & 21,989 & 21,989 \\
\hline 2 & 1,165 & 9,706 & 52,458 & 2,31 & 19,672 & 41,660 \\
\hline 3 & 1,046 & 8,717 & 61,176 & 2,32 & 19,515 & 61,176 \\
\hline 4 & ,859 & 7,158 & & & & 68,334 \\
\hline 5 & ,771 & 6,423 & & & & 74,757 \\
\hline 6 & ,683 & 5,690 & & & & 80,446 \\
\hline 7 &, 500 & 4,165 & & & & 84,612 \\
\hline 8 & ,429 & 3,578 & & & & 88,190 \\
\hline 9 & ,410 & 3,414 & & & & 91,604 \\
\hline 10 & ,372 & 3,098 & & & & 94,702 \\
\hline 11 & ,349 & 2,912 & & & & 97,614 \\
\hline 12 & 0.286 & 2.385 & & & & 100 \\
\hline
\end{tabular}

Yapılan faktör analizinde birinci faktörün alfa değerinin 0,805 , ikinci faktörün 0,711 ve üçüncü faktörün 0,740 olduğu belirlenmiştir. Bu değerlerin hepsi kabul edilebilir değer olan 0,70 'in üzerinde olduğu için, faktörlerin yeterli düzeyde güvenilirliğe sahip olduğunu görülmüştür.

\section{Demografik Bulgular}

Bu bölümde; ölçeğe ilişkin güvenilirlik analizi sonuçları faktör ve regresyon analizleri; örnek kütleyi oluşturan katılımcıların, demografik özelliklerinden cinsiyetleri, yaşları, eğitim durumları, gelir, medeni ve meslek durumları ölçülmüştür. Elde edilen araştırma verileri Tablolarda verilmiştir. Ankete katılanların demografik özelliklerinin belirlenmesi için frekans tablosu oluşturulmuştur. 
Tablo 1: Katılımcıların Demografik Özellikleri

\begin{tabular}{|c|c|c|c|c|c|}
\hline Cinsiyet & Kişi sayısı & Yüzde (\%) & Medeni Durum & Kişi sayısı & Yüzde\%) \\
\hline Kadın & 172 & 68,3 & Evli & 97 & 38,5 \\
\hline \multirow[t]{2}{*}{ Erkek } & 80 & 31,7 & Bekar & 148 & 58,7 \\
\hline & & & Dul/Boşanmış & 6 & 2,4 \\
\hline Eğitimdurumu & Kişi sayısı & Yüzde (\%) & Yaş & Kişi sayısı & Yüzde(\%) \\
\hline Ilkokul & 18 & 7,1 & 18- 23 & 35 & 13,9 \\
\hline Ortaokul & 24 & 9,5 & 24- 29 & 66 & 26,2 \\
\hline Lise & 59 & 23,4 & $30-34$ & 75 & 29,8 \\
\hline Ön Lisans & 43 & 17,1 & $35-39$ & 40 & 15,9 \\
\hline Lisans & 95 & 37,7 & $40-44$ & 15 & 6,0 \\
\hline $\begin{array}{l}\text { Yüksek } \\
\text { Lisans/Doktora }\end{array}$ & 12 & 4,8 & $45-49$ & 11 & 4,4 \\
\hline \multirow[t]{2}{*}{ Aylikgelir } & \multirow[t]{2}{*}{ Kişi sayısı } & \multirow[t]{2}{*}{ Yüzde (\%) } & 50- 54 & 3 & 1,2 \\
\hline & & & $55-59$ & 7 & 2,8 \\
\hline 501-1000 TL & 38 & 15,1 & Meslek & Kişi sayısı & Yüzde(\%) \\
\hline 1001-1500TL & 45 & 17,9 & SerbestMeslek & 22 & 8,7 \\
\hline $1501-2000 \mathrm{TL}$ & 36 & 14,3 & Tüccar/Sanayici & 7 & 2,8 \\
\hline 2001-2500TL & 46 & 18,3 & Esnaf/iş̧çi & 10 & 4,0 \\
\hline 2501-3000TL & 34 & 13,5 & Özel Sektör Çalışanı & 4 & 17,1 \\
\hline 3001-3500TL & 12 & 4,8 & KamuÇalışanı & 54 & 21,4 \\
\hline 3501-4000TL & 1 & ,4 & Emekli & 8 & 3,2 \\
\hline 4001-4500TL & 1 & 4 & Ev Hanımı & 40 & 15,9 \\
\hline 4501-5000TL & 1 & 4 & Öğrenci & 41 & 16,3 \\
\hline 5001-5500TL & 1 & ,4 & Diğer & 27 & 10,7 \\
\hline 5501-6000TL & 1 & 4 & & & \\
\hline 6000TL ve üzeri & 2 & 8 & & & \\
\hline
\end{tabular}

Tablo 1'e göre araştırmanın \% 68,3'ü kadın, $\% 31,7$ 'ini erkek tüketicilerden oluşturmaktadır. Veri toplama yöntemi aracı olarak kullanılan, internet aracılığıyla online- anket toplanılmıştır. "Bireylerin etkileri ürünlere göre değişim göstermektedir”(Koç, 2007). Yapılan çalışmalarda 'kızların erkeklere oranla dış görünüşlerine daha ilgili oldukları göz önüne alındığında araştırmaya katılanların, cinsiyet dağılımının bu çalışma için uygun olduğu söylenebilir. Araştırmaya katılan tüketicilerin durumları değerlendiğirdiğinde katılımcıların önemli kısmının (\%85,8)18- 39 yaş aralığında, medeni durumlarına göre $(\% 58,7)$ bekar ve eğitim düzeyine sahip oranların $(\% 37,7)$ lisans mezunlarının, lisansüstü mezunlarının oranının $(\% 4,8)$ olduğu, 5001- 3000TL arası gelire sahip \%79,1'lik tüketici geliri olduğu ve Esnaf/iş̧̧i, (\%17,1) Özel sektör çalışanı, $(\% 21,4)$ Kamu çalışanlarından oluştuğu tespit edilmiştir.

\section{Regresyon Analizi Sonuçları}

Çalışmada tüketicilerin LC Waikiki markalarında marka deneyim algılamalarının markalara yönelik bağlılık, tatmin ve güvenin etkisinin ölçülmesi amacıyla regresyon analizinden faydalanılmış ve tüketicilerin LC Waikiki markalarından marka deneyim algılamalarının memnuniyetlerinin bağlılık, tatmin ve güven etkisine bakılmıştır. Elde edilen verilerlerden yola çıkarak marka deneyimi boyutunun; bağlılık, tatmin ve güven arasındaki ilişkileri açıklayan hipotezleri test edebilmek için regresyon analizi uygulanmıştır. Regresyon analizinin anlamlılık derecesini belirleyebilmek için $(F)$ ve $(P)$ değerleri incelenmiștir. Regresyon modelinin anlamlı olup olmadığını incelemek için ANOVA testi uygulanmıştır. ANOVA testi sonucunda ortaya çıkan $F$ değerine karşılık gelen anlamlılık seviyesi, oluşturulan modelin uygun olup olmadığını anlamaya yardımcı olmaktadır. "R" değeri bağımlı değişken ile bağımsı değiş̧ken arasındaki korelasyonu temsil etmektedir. Bu değerin yüksek olması bağımlı ve bağımsız değişkenler arasındaki ilişkinin kuvvetli olduğunu gösterirken, 'R2 " 
değeri ise bağımlı değişkendeki varyansın yüzde kaçının bağımsız değişken tarafından açıklandığını ifade etmektedir.

Yapılan bu çalışmada, çoklu doğrusal regresyon analizi kullanılarak test edilmiş ve bütün araștırma hipotezlerinin test sonuçları özet tablo halinde hazırlanmış ve yorumlanmıştır:

Tablo 3: Marka Deneyiminin, Tatmin, Bağımlılık ve Güven Üzerindeki Etkisi RegresyonAnalizi

\begin{tabular}{|c|c|c|c|c|}
\hline & $\mathrm{R}$ & $\mathrm{R} 2$ & $\mathrm{~F}$ & Sig \\
\hline Marka Sadakati &, 516 & , 1226 & 90,800 & $0,0 o b$ \\
\hline Marka Güveni &, 532 & ,1283 & 98,441 & $0,0 o b$ \\
\hline Marka Tatmini & ,274 & 1075 & 20,236 & $0,0 o b$ \\
\hline Değișkenler & & $\begin{array}{l}\text { Standardize Reg. } \\
\text { Katsayısı }\end{array}$ & T değerinin anlamlılık düzeyi & Sig değerinin anlamlılık düzeyi \\
\hline Marka Bağ|ılığı & & 1,516 & $\begin{array}{l}14,420 \\
9,529 \\
\end{array}$ & $\begin{array}{l}, 0,000 \\
, 0,000\end{array}$ \\
\hline Marka Güveni & & 1,532 & $\begin{array}{l}11,500 \\
9,9922\end{array}$ & $\begin{array}{l}, 0,000 \\
, 0,000\end{array}$ \\
\hline Marka Tatmini & & 1,274 & $\begin{array}{l}14,057 \\
4,498\end{array}$ & $\begin{array}{l}, 0,000 \\
, 0,000\end{array}$ \\
\hline
\end{tabular}

Analiz sonuçları incelendiğinde ' $F$ 'değerinin marka bağlılığı için $(90,800)$, marka güveni için $(98,441)$ ve marka tatmini için $(20,236)$ olduğu ve ve bu değere ait önem seviyesinin $\mathrm{p}=0,000<0,05$ olduğu görülmektedir. Bu sonuçlar neticesinde elde edilen regresyon modelinin anlamlı olduğu ve tahminlerde kullanılabileceği belirlenmiştir.

Araştırmadaki bulgular incelendiğinde, öncelikle elde edilen regresyon modelinin istatistiki olarak anlamlı olup olmadığını belirlemek için, marka deneyimi boyutunun marka bağlılığı arasında pozitif yönlü ilişki olduğu (R) değeri: ,516 ve belirlilik kat sayısının $\left(R^{2}\right)$ : 1226 olduğu bulunmuştur. Araştırmanın sonuçlarına göre LCW markasına karşı oluşan marka bağlılığındaki değişikliklerin marka deneyimindeki algılamalardan oluştuğu belirlenmiştir. Marka bağlılığı ile deneyim arasında pozitif (,404) bir ilişkinin olduğu görülmüştür. Belirlenen $t$ değerinin 0,05 'den küçük olduğu ve bu ilişkinin istatistiksel açıdan anlamlı olduğu görülmektedir. ( $t=9,529, p=0,00 t \quad 0)$. LCW markasının tüketicilerin düșünceleri doğrultusunda marka deneyimi boyutunun katılımcıların marka bağlılığı üzerinde etkili olduğu belirlenmiştir. H3: Tüketicilerin marka deneyimi algısının, marka bağlılığı üzerinde istatiksel olarak anlamlı olduğu görülmüştür.

Tablo 3 incelendiğinde, marka güveni (f) değerinin $(98,441)$ olduğu ve bu değere ait önem seviyesinin 0,05 'ten küçük olduğu görülmektedir. Bu nedenle elde edilen regresyon modelinin anlamlı olduğu ve tahminlerde kullanılabileceği sonucuna ulaşılmaktadır. Marka güveni ile marka deneyimi boyutu arasında pozitif (,397) bir ilişkinin olduğu ve $t$ - değerinden bu ilişkinin istatistiksel açıdan anlamlı olduğu görülmektedir. ( $t=9,922, p=0,000)$. Marka deneyimi boyutu ile marka güveni arasında, (R) değeri: ,532 ve belirlilik kat sayısının $\left(R^{2}\right)$ : ,1283 olduğu ve pozitif yönlü bir ilişkinin olduğu belirlenmiştir. LCW markasının tüketicilerin düşünceleri doğrultusunda marka deneyimi boyutunun marka güveni üzerinde etkisi olduğu belirlenmiştir.

$\mathbf{H}_{2}$ : Tüketicilerin marka deneyimi algısının, marka güveni üzerinde istatiksel olarak anlamlı bir etkisi vardır hipotezi kabul edilmiştir.

Tablo 3 incelendiğinde marka değeri boyutunun $(f)$ değerinin marka tatmini $(f)$ 
değeri: $\quad 20,236, \quad(p<0,005) \quad$ olarak bulunmuştur. Bu değere ait önem seviyesinin 0,05 'ten küçük olduğu görülmektedir. Bu nedenle elde edilen regresyon modelinin anlamlı olduğu ve tahminlerde kullanılabileceği sonucuna ulaşılmaktadır. Marka tatmini ile marka deneyimi boyutu arasında da pozitif $(, 236)$ bir ilişki vardır ve tdeğerinden bu ilişkinin istatistiksel açıdan anlamlı olduğunu görülmektedir. ( $\mathrm{t}=4,498$, $\mathrm{p}=0,000)$. Marka tatmini (R) değeri:,274 ve belirlilik kat sayısının $\left(R^{2}\right)$, 1075 olarak bulunmuş ve sonuçların pozitif yönlü ilişkinin olduğu ve anlamlı olduğu sonucuna varılmıştır. LCW markasının tüketicilerin düşünceleri doğrultusunda marka deneyimi boyutunun marka tatmini üzerinde etkisi olduğu belirlenmiștir. $\mathbf{H}_{1}$ Tüketicilerin marka deneyimi algısının, marka tatmini üzerinde istatiksel olarak anlamlı bir etkisi vardır hipotezi kabul edilir.

Hesaplanan bu regresyon analizi modelinde (marka bağlılığı, güveni, tatmini) bağımlı değişkenler ile, (marka deneyimi) boyutunun bağımsız değișkenin etkisi arasında doğrusal ilișki, istatistiksel olarak anlamlı düzeyde olduğu görülmüștür. $(p<0,005)$.

Tablo 4: Cinsiyetin Marka Deneyimi Üzerindeki Etkisine Yönelik Bağımsız t -testi Analiz

\begin{tabular}{|c|c|c|c|c|c|c|}
\hline Puan & Cinsiyet & N & Mean & SS & t & P \\
\hline \multirow{2}{*}{$\begin{array}{c}\text { Marka Deneyimi } \\
\text { Ortalaması }\end{array}$} & Kadın & 172 & 3,0087 &, 429 & 1,217 &, 225 \\
\cline { 2 - 7 } & Erkek & 80 & 3,0865 &, 552 & & \\
\hline
\end{tabular}

Tablo 4'de sunulan, marka deneyimi algılamalarına ilișkin ortalama puanlarının cinsiyetlerine göre karşılaştırılmasında yararlanılan bağımsız örneklemler için, t- testi sonuçları incelendiğinde kadın ve erkek katılımcıların LC Waikiki markasına karşı oluşturdukları deneyim algılamalarının birbirlerine yakın ortalamalara sahip oldukları görülmüştür. Araştırmaya katılan 80 erkek katılımcının marka deneyim algıları 3,0865 iken, araştırmaya katılan 172 kadın katııımcının marka deneyimi algıları 3,0087 olarak bulunmuştur. Kadın ve erkek katılımcıların marka deneyim algılamaları ortalamalarındaki bu firkin anlamlı bir fark olup olmadığını belirlemek için ( $p$ değerine) bakılmıştır. Değer (,225>0,05) olduğundan kadın ve erkek katılımcıların LC Waikiki marka deneyim algılama düzeylerinin anlamlı bir farklılık görülmemiştir. Bu bulgulara dayalı olarak cinsiyet, marka deneyimi algılamalarını etkileyen bir faktör olmadığı $\mathbf{H}_{4}$ : "Marka deneyimi boyutunun katılımcıların cinsiyetlerine göre farklılık göstermediği tespit edilmiştir.

Tablo 5: Marka Deneyimlerinin Puanlarına Illişkin Katılımcıların Aylık Gelir Değişkenine Göre Tek Yönlü Varyans Analizi (ANOVA) ve Tukey Sonuçları

\begin{tabular}{|c|c|c|c|c|c|c|}
\hline \multirow{12}{*}{$\begin{array}{l}\text { Marka deneyimi } \\
\text { ortalama }\end{array}$} & Gruplar & $\begin{array}{l}\text { Kişi } \\
\text { sayısı }\end{array}$ & Ortalama & $\begin{array}{l}\text { Standart } \\
\text { sapma }\end{array}$ & $\begin{array}{l}\mathrm{F} \\
\text { değeri }\end{array}$ & $\begin{array}{l}\text { Anlamlılık } \\
\text { (p) }\end{array}$ \\
\hline & & & & & 2,915 & ,004 \\
\hline & Öğrenci & 41 & 3,1098 & 43975, & & \\
\hline & Diğer & 27 & 3,2262 & ,18456 & & \\
\hline & $\begin{array}{l}\text { Özel Sektör } \\
\text { Çalışanı }\end{array}$ & 43 & 3,2333 & 16574 & & \\
\hline & Kamu Çalışanı & 54 & 2,9632 &, 54624 & & \\
\hline & Ev Hanımı & 40 & 3,0880 &, 42628 & & \\
\hline & Serbest Meslek & 22 & 3,5104 & ,85963 & & \\
\hline & Tüccar/Sanayici & 7 & 3,0896 &, 41102 & & \\
\hline & Esnaf/İşçi & 10 & 2,8618 & ,49917 & & \\
\hline & Emekli & 8 & 2,8858 &, 32204 & & \\
\hline & Toplam & 252 & 3,0334 & ,47236 & & \\
\hline
\end{tabular}


Tablo 5'deki veriler incelendiğinde, LC Waikiki markasında katılımcıların meslek değișkenlerinin incelenmesinde, serbest meslek ortalamasının 3,5104, özel sektör çalışanı ortalamasının 3,2333, diğer mesleklerin 3,2262, öğrenci ortalamasının 3,1098, tüccar/ sanayici ortalamalarının 3,0896, kamu çalışanı ortalamalarının 2,9632, emekli ortalamalarının 2,8858 ve esnaf/işçi ortalamalarının 2,8618 olduğu, $F$ değerinin 2,915 ve $p$ değerinin de ,004 olduğu belirlenmiştir. Bu verilere göre marka deneyimi boyutunun, katılımcıların mesleklerine göre farklılık gösterdiği tespit edilmiştir. Bu farklılıkların hangi gruplardan kaynaklandığını belirleyebilmek için çoklu karşılaştırma testlerinden Tukey HSD testi uygulanmıştır. Test sonuçlarına göre emekli olanların, diğer sekiz meslekle karşılaştırılmasında, emekli grup ortalamaları ile öğrenci ve diğer mesleklerin sahip olduğu grup ortalamalarının arasında marka deneyimi algılamalarında farklıık olduğu görülmüştür. $\quad(F=2,915 ; \quad p<0.05$. Bununla birlikte öğrenci mesleğine sahip bulunan grup ortalamasının emekli ortalamaları arasında da fark olduğu belirlenmiștir. Yine Tukey HSD 'e göre diğer meslek grubunun sekiz meslek grubu ile karşılaştırılmasında; emekli grup ortalamaları arasında anlamlı bir farklılığın olduğu belirlenmiş ve $\mathbf{H}_{5}$ : "Marka deneyimi boyutunun katılımcıların mesleklerine göre farklılık gösterdiği tespit edilmiştir.

Tablo 6: Marka Deneyimlerinin Puanlarına İlișkin Katılımcıların Eğitim Düzeyi Değișkenine Göre Tek Yönlü Varyans Analizi (ANOVA) Sonuçları

\begin{tabular}{|l|l|l|l|l|l|c|}
\hline \multirow{4}{*}{$\begin{array}{l}\text { Marka } \\
\text { deneyimi } \\
\text { ortalama }\end{array}$} & Kruplar & Kişi sayısı & Ortalama & $\begin{array}{l}\text { Standart } \\
\text { sapma }\end{array}$ & F değeri & Anlamlılık (p) \\
\cline { 2 - 7 } & Ilkokul & & & & 1,517 &, 173 \\
\cline { 2 - 7 } & Ortaokul & 24 & 3,3009 &, 37063 & & \\
\cline { 2 - 7 } & Lise & 59 & 3,0069 &, 32407 & & \\
\cline { 2 - 7 } & Ön Lisans & 43 & 3,0601 &, 65144 & & \\
\cline { 2 - 7 } & Lisans & 95 & 2,9553 &, 47667 & & \\
\cline { 2 - 7 } & $\begin{array}{c}\text { Yüksek } \\
\text { Lisans/Doktora }\end{array}$ & 12 & 3,0417 &, 30256 & & \\
\cline { 2 - 7 } & Toplam & 252 & 3,0334 &, 47236 & & \\
\hline
\end{tabular}

Yukarıdaki tablo incelendiğinde, marka deneyimi algılamalarına ait ortalamalarına ilişkin değerlerin eğitim düzeylerine yönelik görüşlerine ilişkin ortalamalar incelendiğinde ilkokul mezunu olan katılımcıların marka deneyimi algılamalarında ortalama 3,3009, Ön Lisans mezunlarının 3,0601, Lise mezunlarının 3,0692, Ortaokul mezunlarının 3,0069 ve Yüksek Lisans/Doktora mezunlarının 3,0417 olduğu belirlenmiştir. F değerinin de 1,517 ve anlamlılık değerinin 0,173 olduğu görülmektedir. Çalışmadan çıkan sonuçta $\mathbf{H}_{6}$ : Marka deneyimi boyutunun katılımcıların eğitim seviyelerine göre farklıık göstermediği tespit edilmiștir. 
Tablo 7: Marka Deneyimlerinin Puanlarına Ilişkin Katılımcıların Yaş Değişkenine Göre Tek Yönlü Varyans Analizi (ANOVA) Sonuçları

\begin{tabular}{|c|c|c|c|c|c|c|}
\hline \multirow{11}{*}{$\begin{array}{l}\text { Marka deneyimi } \\
\text { ortalama }\end{array}$} & Gruplar & Kişi sayısı & Ortalama & $\begin{array}{l}\text { Standart } \\
\text { sapma }\end{array}$ & F değeri & Anlamlılık (p) \\
\hline & & & & & 1,708 & ,108 \\
\hline & $18-23$ & 35 & 2,8976 &, 53668 & & \\
\hline & $24-29$ & 66 & 2,9508 &, 38922 & & \\
\hline & $30-34$ & 75 & 3,0922 & ,43400 & & \\
\hline & $35-39$ & 40 & 3,0417 &, 50637 & & \\
\hline & $40-44$ & 15 & 3,0667 & ,40360 & & \\
\hline & $45-49$ & 11 & 3,2197 & ,80646 & & \\
\hline & $50-54$ & 3 & 3,2778 & ,20972 & & \\
\hline & $55-59$ & 7 & 3,3452 & ,39508 & & \\
\hline & Toplam & 252 & 3,0334 & ,47236 & & \\
\hline
\end{tabular}

Tablo 7'de görüldüğü LCWaikiki marka deneyimlerine ait örneklemde katılımcıların yaş düzeylerine göre farklılık arz edip etmediğine ilişkin Anova testi yapılmıştır. Katılımcıların yaşları 18-23 olanların marka deneyimi algılamalarına ilișkin ortalamaları 2,8976, 24-29 olanların 2,9508, 30-34 olanları 3,30922, 35-39 olanların 3,0417, 40-44 olanların 3,0667, 45-49 olanların 3,2197, 50-54 olanların 3,2778, 55-59 olanların 3,3452 olduğu, bunlara ait $\mathrm{F}$ değerinin de 1,708 ve önem seviyesinin 0,108 olduğu görülmektedir. Bu sonuçlar,005 anlamlılık düzeyine göre; $\mathrm{H}_{7}$ : marka deneyimi boyutunun katılımcıların yaş seviyelerine göre farklılık göstermediği tespit edilmiştir.

Tablo 8: Marka Deneyimlerinin Puanlarına ilişkin Katılımcıların Aylık Gelir Değişkenine Göre Tek Yönlü Varyans Analizi (ANOVA) Sonuçları

\begin{tabular}{|c|c|c|c|c|c|c|}
\hline \multirow{11}{*}{$\begin{array}{c}\text { Marka } \\
\text { deneyimi } \\
\text { ortalamaları }\end{array}$} & Gruplar & Kişi sayısı & Ortalama & $\begin{array}{l}\text { Standart } \\
\text { sapma }\end{array}$ & $\begin{array}{l}\mathrm{F} \\
\text { değeri }\end{array}$ & Anlamlılık (p) \\
\hline & & & & & 2,027 & ,023 \\
\hline & 500 TL ve altı & 34 & 2,8456 &, 52710 & & \\
\hline & 501-1000 TL & 38 & 2,9079 & ,43444 & & \\
\hline & 1001-1500 TL & 45 & 3,1741 &, 50591 & & \\
\hline & $1501-2000 \mathrm{TL}$ & 36 & 2,9676 &, 51419 & & \\
\hline & $2001-2500 \mathrm{TL}$ & 46 & 3,0743 & ,30288 & & \\
\hline & $2501-3000 \mathrm{TL}$ & 34 & 3,2206 &, 50121 & & \\
\hline & $3001-3500 \mathrm{TL}$ & 12 & 2,9653 & ,39482 & & \\
\hline & $3501-4000 \mathrm{TL}$ & 1 & 3,0833 & . & & \\
\hline & 4001-4500 TL & 1 & 2,5833 & . & & \\
\hline & 4501-5000 TL & 1 & 2,9167 & . & & \\
\hline & $5001-5500 \mathrm{TL}$ & 1 & 3,8333 & . & & \\
\hline & $5501-6000 \mathrm{TL}$ & 1 & 2,6667 & . & & \\
\hline & 6000 TL ve üzeri & 2 & 2,9583 & ,17678 & & \\
\hline & Toplam & 252 & 3,0334 & ,47236 & & \\
\hline
\end{tabular}

Tablo 8'deki veriler incelendiğinde, katılımcıların LCWaikiki marka deneyimi boyutuna ilişkin görüşlerinin, kişilerin gelir düzeylerine göre incelendiğinde, $500 \mathrm{TL}$ ve altı olan katılımcıların marka deneyimi algılarına ilişkin ortalamaları 2,8456, 1001-1500 TL olan 45 katılımcının ortalamaları 3,1741, 1501-2000 TL olanların ortalamaları ,2,9676,
2001-2500 TL olanların ortalamaları, 3,0743, 2501-3000 TL olanların ortalamaları 34 kişi ile 3,2206, 3001-3500 TL olanların ortalamalarının,2,9653, 3501-4000 TL olanların ortalamalarının 3,0833, 4001-4500 TL olanların ortalamalarının 2,5833, 4501-5000 TL olanların ortalamalarının 2,9167, 5001-5500 TL olanların ortalamalarının 3,8333,5501-6000 TL 
olanların ortalamalarının 2,6667 ve $6000 \mathrm{TL}$ ve üzeri geliri olanların ortalamalarının 2,9583 olduğu, (F) değerinin 2,027 ve (p) değerinin ise ,023 olduğu sonucuna varılmıştır. Bulgu, katılımcıların marka deneyimine ilișkin görüş ortalamaları ile katılımcıların aylık kazancı arasında anlamlı ilişki olmadığı gerçeğinden hareketle tesadüfî olarak da algılanabilecek bir sıralamadır. Ailelerin aylık gelir seviyesi arttıkça $\mathbf{H}_{8}$ : marka deneyimi boyutunun katılımcıların gelir seviyelerine göre farklılık göstermediği tespit edilmiştir.

Tablo 9: Marka Deneyimlerinin Puanlarına ilișkin Katılımcıların Medeni Durumları DeğişkenineGöre Tek Yönlü Varyans Analizi (ANOVA) Sonuçları

\begin{tabular}{|c|c|c|c|c|c|c|}
\hline \multirow{5}{*}{$\begin{array}{l}\text { Marka } \\
\text { deneyimi } \\
\text { ortalama }\end{array}$} & Gruplar & Kişi sayısı & Ortalama & $\begin{array}{l}\text { Standart } \\
\text { sapma }\end{array}$ & F değeri & Anlamlılık (p) \\
\hline & Bekar & 97 & 3,00 & 465 & 2,078 & 104 \\
\hline & Evli & 148 & 3,07 &, 469 & & \\
\hline & $\begin{array}{c}\text { Dul/ } \\
\text { Boşanmış }\end{array}$ & 6 & 2,80 & ,528 & & \\
\hline & Toplam & 252 & 3,03 & ,472 & & \\
\hline
\end{tabular}

Yukarıda Tablo 9‘da görüldüğü gibi LCWaikiki markasında katılımcıların medeni durumlarına göre farklılık gösterip göstemediğini belirlemek için, tek yönlü varyans analizi (ANOVA) uygulanmıştır. Marka deneyimi ortalamalarına göre,medeni durumu evil olanların ortalamalarının 3,07, medeni durumu bekar olanların ortalamalarının 3,00 ve dul/boşanmış olanların ortalamalarının 2,80 olduğu, $F$ değerinin 2,078 ve $p$ değerinin ise ,104 olduğu sonucuna varılmıştır. Bu sonuçlara göre; $\mathbf{H}_{8}$ : marka deneyimi boyutunun katılımcıların medeni durumlarına göre farklılık göstermediği tespit edilmiştir.

\section{Sonuç, Tartışma ve Öneriler}

Hizla gelişen teknolojik gelişmeler ve değişimlerle birlikte işletmelerin, marka tanınırılığını oluşturmaları, pazarda avantaj sağlamaları ve oluşan rekabet karşısında varlıklıklarını sürdürebilmeleri gerekmektedir. Sektörün tüketiciler karşısında onların istek ve ihtiyaçları doğrultusunda ürünlerini oluşturmaları ve piyasaya sunmaları gerekmektedir. Günümüzün moda anlayışında tüketicilerin modayı takip edebilmesi adına en çok hazır giyim ürünleri tercih etmektedirler. Bu nedenle sektörün kendi markalarına çekmeleri ve onlara güvenen sadık tüketicilerin oluşturulması amaçlanmalıdır.
Tüketicilerin bir markayı sadece kullanması, onun görsel ve işitsel kanallarını tercih etmesi yada o ürüne sahip olması, markaya sadık kalmasında yeterli olmamaktadır. Markalar ile yaşanılan deneyimler, kişilerin duygularına hitap ederek, onlara sosyal ve davranışsal değerler sağlayarak, markalarda bir kimlik oluştur-malarını sağlamaktadırlar. Böylece markalar-da ürün veya hizmetle yaşanılan deneyimler tüketicilere keyif veren ya da bir daha talep edilmeyen durumlara dönüşebilmektedir.

Marka deneyimleri ile demografik özellikler arasında anlamlı farklılık olup olmadığı sorgulanmış ve şu sonuçlara ulaşılmıştır:

Modern düzenin ve gelişen teknolojilerin etkisiyle birlikte kadınların estetik, güzelleşme, beğenilme, statü kazanma, özgürlük ve yaratıcılığa dikkat eder hale geldikleri düşünülürse LC Waikiki giysi markalarını genellikle 172 kişi ile kadınların, 80 kişi ile erkeklerin tercih ettikleri ve marka deneyimi boyutunun katılımcıların cinsiyetlerine göre farklılık göstermediği tespit edilmiştir.

LC Waikiki markasını tüketen katılımcıların mesleklerine göre, marka deneyimi algılamalarında anlamlı farklılıkların bulunduğu belirlenmiştir. Ortalamalar değerlendirildiğinde serbest meslek 3,5104, özel sektör çalışanı 3,2333 olduğu görülmüştür. LC Waikiki markası için farklılığın emekli/öğrenci ile emekli/diğer meslekler 
arasından kaynaklandığı görülmüştür.

Tüketicilerin eğitim seviyesine göre değerlendirilmesinde, genellikle lisans ve üstü grubun yoğun olduğu ve tüketicilerin marka deneyimi algısı arasında LC Waikiki kullanıcıları için anlamlı farklılıkların tespit edilmediği belirlenmiştir.

Katılımcıların yaşları 18-23 olanların marka deneyimi algılamalarına ilişkin ortalamaları 2,8976, 24-29 olanların 2,9508, 30-34 olanları 3,30922, 35-39 olanların 3,0417, 40-44 olanların 3,0667, 45-49 olanların 3,2197, 50-54 olanların 3,2778, 55-59 olanların 3,3452 olduğu belirlenmiş ve tüketicilerin yaş değișkeni ile marka deneyim algılamaları arasında anlamlı bir farklılığın olmadığı tespit edilmiştir.

Tüketicilerin gelir dağılımlarına bakıldığında ise 500TL ve altı \%13,5 iken, 5001-3000TL arası gelire sahip \%79,1'lik tüketici gelir grubundan oluşmaktadır. Belirlenen veriler bize göstermektedir ki genellikle tüketiciler orta gelire sahip olduğu ve medeni durumun marka deneyim algılamalarında etkili olmadığını göstermektedir.

Yapılan regresyon analizi sonuçları değerlendirildiğinde, marka deneyimi boyutunun marka bağlılığı arasında pozitif yönlü ilişkinin olduğu, LC Waikiki markasına karşı oluşan marka bağlılığındaki değişikliklerin marka deneyimindeki algılamalardan oluştuğu belirlenmiştir. Marka güveni ile marka deneyimi boyutu arasında da pozitif yönlü bir ilişkinin olduğu, tüketicilerin marka deneyimi algısının, marka güveni üzerinde istatiksel olarak anlamlı bir etkisinin olduğu belirlenmiștir. Aynı zamanda marka deneyim algıları ile tatmin arasındaki ilişki incelendiğinde, LC Waikiki markasının tüketici-lerin düşünceleri doğrultusunda marka deneyimi boyutunun marka tatmini üzerinde etkisi olduğu belirlenmiştir. Hesaplanan bu regresyon analizi modelinde (marka bağlılığı, güveni, tatmini) bağımlı değişkenler ile, (marka deneyimi) boyutunun bağımsız değişkenin etkisi arasında doğrusal ilişki, istatistiksel olarak anlamlı düzeyde olduğu görülmüştür. $(p<0,005)$.
Araştırma sonucunda elde edilen bulgulardan yola çıkılarak şu öneriler getirilebilir:

- Markalarla oluşturulan olumlu deneyim ve güven bağlı tüketiciler oluşturacaktır. Bu durumda tüketicilerin markaları satın almalarına etkili olacaktır. Markalar ile yaşatılan olumlu deneyim bağlı tüketici grubu oluşturacaktır. Pazarlama, müşterinin gereksinimlerini ve beklentilerini iyi tanıyarak, bu hizmetin nasıl sunulacağının iyi planlanması, ürünün piyasa şartlarına göre fiyatlandırılması ve sonrasında markaların tüketicilere ulaştırılması tutundurulması açısından önemli olacağı düşünülmektedir.

- Markalara (LCWaikiki) karşı oluşturulan olumlu marka deneyimleri arttıkça, tüketicilerin tatmin olma seviyeleri artacaktır. Marka ile yaşanılmış olan olumlu deneyim tatmin olmuş tüketicilere dönüşecek, böylece marka ile olumlu deneyim yaşanılacaktır.

- Büyük mağaza markalarında işletmelerin tüketicilerde (mağaza atmosferini, satış elemanlarını, reyonların düzenlenmesi, kullanılan müzik, oluşturulan pazarlama karmaları, kampanyalar, fiyatlandırma, kalite vs) bir bütünlük halinde tüketiciyi memnun etmeli ve markaya karşı olumlu duygular yaratarak tüketicilerin ürün yada hizmetleri tekrar satın alma isteği uyandırılmalıdır.

- Duyumsal marka deneyimleri yaşatılmalı, marka tatmini yaşatılarak deneyim arttırılmalıdır.

- Bu çalıșmada, sadece giyim sektörü olan LC Waikiki markası ele alınarak çalışılmıştır.Yapılacak yeni çalışmalarda diğer hizmet sektörleri de incelenmelidir. Bu açıklamaların sonucunda marka deneyiminin bağlılık, tatmin ve güvenle ilişkili olabileceği belirlenmiştir. Çalışmaların sonuçlarının işletmeciler açısından önemli katkılar sağlayacağı düşünülmektedir. Markalar ile edindiğimiz deneyimler ile tüketiciler arasında bir tatmin bağı yaşadıklarını ve bunun neticesinde ise bağlılığa dönüştüğü unutmamak gerekmektedir. 
Kaynakça

Alemdar, Mine Yeniçeri. "Duygusal Pazarlamada Değer Yıldızı Modeli Beyaz Eşya TV Reklam Mesajları Üzerine Bir İnceleme" (2012)." Global Media Journal: Turkish Edition 3.5, 209-245.

Akdeniz, Ar Aybeniz. "Marka ve Marka Stratejileri." Detay Yayınları 3 (2004).

Akkuş, Gülizar, T. Şükrü Yapraklı, \& Çetin Akkuș. Online Müșteri Deneyiminin Güvene Etkisi: Online Alışveriş Yapan Tüketiciler Üzerine Bir Araştırma. (A. Ü. ABD, Dü.) The Journal of Academic Social Scrence(29), 403425.

Akyüz, Ahmet Mutlu. "Çevrimiçi hazır giyim ürünleri tüketiminde müşteri tatmini: Doğu Karadeniz örneği." (2014). Doğuş Üniversitesi Dergisi, 15(1), 97.

Bașer, Ibrahim Uğur. "Tüketicilerin Marka Deneyimi Algısının Marka Güveni, Tatmini, Sadakati Üzerindeki Etkisi ve Bir Araştırma." Yayınlanmamış Doktora Tezi. Marmara Üniversitesi Sosyal Bilimler Enstitüsü (2011).

Bayuk, M. Nedim, \& Ferit Küçük. "Müşteri tatmini ve müşteri sadakati ilişkisi." (2007). Marmara Üniversitesi i.i.B.F. Dergisi, 22(1), 285292.

Brakus, J. Joško, Bernd H. Schmitt, \& Lia Zarantonello. "Brand experience: what is it? How is it measured? Does it affect loyalty?." Journal of marketing 73.3 (2009): 52-68.

Büyük, Hatice Dağcı, Aysel Erciş, \& Bahar Türk. "Ambalajlı Dondurma Sektöründe Marka Sadakatine Etki Eden Faktörler." Atatürk Üniversitesi Sosyal Bilimler Enstitüsü Dergisi 18.3 (2014), 275-292.

Çabuk, Serap, \& Fatma Demirci Orel. "Marka karakteristikleri ile marka ve üretici firmaya duyulan güven arasındaki ilişkilerin belirlenmesi: Çukurova Üniversitesi ölçeğinde bir araştırma." Çukurova Üniversitesi Sosyal Bilimler Enstitüsü Dergisi 17.1 (2008), 103-116.
Çetin, Kamile. "Kadın Tüketicilerin Giysi Satın Alma Davranışları Ve Marka Bağımlıı̆̆ı." (2016): 22-40.

Delgado-Ballester, Elena, \& José Luis Munuera-Alemán. "Does brand trust matter to brand equity?." Journal of product \& brand management 14.3 (2005): 187-196.

Devrani, Tülay Korkmaz. "Marka Sadakati Öncülleri: Çalışan Kadınların Kozmetik Ürün Tüketimi Üzerine Bir Çalışma." Süleyman Demirel Üniversitesi iktisadi ve idari Bilimler Fakültesi Dergisi 14.3 (2009), 407-421.

Doğan, Volkan, \& Behçet Yalın Özkara. "Internet ortamında markaya güvenin online markaların imajı üzerindeki rolü." IUYD4.2 (2013): 5-20.

Doyle, Peter, \& Gülfidan Barıș. Değer temelli pazarlama: Şirketinizi büyütmek ve hissedar değeri yaratmak için pazarlama stratejileri. Kapital Medya, 2003.

Eren, Selim Said, \& Aydın Erge. "Marka Güveni, Marka Memnuniyeti, Müşteri Değerinin Tüketicilerin Marka Sadakati Üzerindeki Etkisi." Journal of Yasar University 7.26 (2012), 4455-4482.

Erge, Aydın. (2011). Bolu ili Tüketicilerinin Piliç Eti Marka Sadakati Üzerine Marka Güveni, Marka Memnuniyeti, ve Müşteri Değerinin Etkisi. Yayınlanmamış Yüksek Lisans Tezi. Abant İzzet Baysal Üniversitesi Sosyal Bilimler Enstitüsü.

Gürbüz, Ahmet, \& Melek Doğan. "Tüketicilerin markaya duyduğu güven ve marka bağılılığı ilişkisi." Uluslararası Yönetim iktisat ve Işsletme Dergisi 9.19 (2013): 239-258.

Hair, J., et al. "Multivariate data analysis New Jersey: Prentice-Hall." (1998).

ilgüner, Muhterem. "Türkiye" de Marka Yaratma ve Yaşatmanın Altın Kuralları." Rota Yayıncilık: Istanbul (2006).

İri, Ruhan, \& Mehmet Emin İnal. "Bir Hazır Giyim Markasının Pazardaki Değişim Hikâyesi: LC Waikiki Örneği." Süleyman Demirel Üniversitesi Iktisadi ve İdari Bilimler Fakültesi Dergisi 16.1 (2011), 445-469. 
İslamoglu, A. H. "Pazarlama Yönetimi (Stratejik Yaklaşım).(6. Baskı)." Istanbul: Beta Yayinları (2013).

Johnston, Robert, \& Xiangyu Kong. "The customer experience: a road-map for improvement." Managing Service Quality: An International Journal 21.1 (2011): 5-24.

Koç, Erdoğan. Tüketici davranışı ve pazarlama stratejileri: Global ve yerel yaklașım. Seçkin Yayıncilık, 2012.

KILIÇ, Solmaz. "Hizmet Pazarlamasında Müșteri Memnuniyeti." İstanbul Üniversitesi., SBE-Basılmamış Yüksek Lisans Tezi, İstanbul(1998).

Kıncal, Remzi. Bilimsel Araștırma Yöntemleri.Ankara: Nobel Akademik Yayıncılık Danışmanlık, 2015.

Kohen, A. (2015 , Erişim Tarihi: 17, 03, 2015). Çağrı Merkezinde Yaşanan Deneyim Marka Sadakatini Etkiliyor. (D. i. Yayıncılığı, Dü.) Sektörel.com, haber ve rehber.

Kurtz, D. L., \& Boone, L. E. (2013). Çağdaş İşletme (Contemporary Busıness). (A. Yalçın, Çev.) Ankara: Nobel Akademik Yayıncılık Eğitim Danışmanlık,338.

Nakip, M. (2006). Pazarlama Araştırmaları Teknikler ve SPSS Destekli Uygulamalar. Seçkin Yayıncılık, (2. Baskı), 424.

Oliver, R. L. (1997). Satis faction: A Behavioral Perspective on The Customer. Boston: İrwin Mcgraw Hill.

Onur, M. B. (2011). Marka Kişiliği ve Marka Sadakatini Etkileyen Faktörlerin ilişkisi ve Hazır Giyim Sektöründe Bir Uygulama Yü. (Y. L. Tezi, Dü.) İstanbul: Marmara Üniversitesi Sosyal Bilimler Enstitüsü İșletme AnaBilim Dalı Üretim Yönetimi ve Pazarlama Bilim Dalı,78.

Özdemir, M., \& Koçak, A. (2012). ZULGANEF (2006) ALINTI ilişskisel Pazarlama Çerçevesinde Marka Sadakatinin Oluşumu ve Bie Model Önerisi. Ankara Üniversitesi SBF Dergisi, 67(2), 127- 156.

http://corporate.lcwaikiki.com/hakkimizda (Erişim: 25.04.2017).
Özturkcan, S., \& Kervenoael, R. D. (2008). Turkish E- Bonking: Lonsumer Experiences. 13 th Notional Marketing Congress.

Peter, Doyle. "Değer Temelli Pazarlama: Şirketinizi Büyütmek ve Hissedar Değeri Yaratmak çin Pazarlama Stratejileri." Çeviren: Gülfidan Barış (2003).

Pine, B. Joseph, \& James H. Gilmore. "Welcome to the experience economy." Harvard business review 76 (1998): 97-105.

Sakınç, Ö. (2014). Müşteri Ilişkileri Yönetimi ve Satış Gücü Niteliklerinin Firma Marka İmajına Etkisi: Ankara illinde îlaç Sektöründe Bir Uygulama Yüksek Lisans Tezi. Ankara: Atılım Üniversitesi Sosyal Bilimler Enstitüsü Işletme Yönetimi Ana Bilim Dalı,61.

Şahin, A. (2011). Marka Deneyimi ve İletişiminin Marka Sadakatine Etkisinde Marka İlișki Kalitesinin Rolü. Gebze: Gebze Yüksek Teknoloji Enstitüsü Sosyal Bilimler Enstitüsü42- 48.

Türkay, A. (2011). Satın Alma Davranışları Açısından Üniversite Öğrencileri Arasında Marka Bağlılığının Önemi: Batı Akdeniz Üniversitesinde Bir Uygulama. Süleyman Demirel Üniversitesi Sosyal Bilimler Enstitüsü.

Yayınoğlu, Pınar Eraslan. "Bütünleşik Marka Iletişimi Temeller, Stratejiler, Uygulamalar ve T-Box Örneği." ILETi-Ş-iM5.5 (2006).

Yıldız, Yavuz, A. Y. Canan, \& Selhan Özbey. "Futbol Takımlarında Tüketici Temelli Marka Değeri: Bir Model Önerisi." Ege Academic Review 12 (2012), 1-10.

Yüksel, Ü., \& Yüksel, A. (2005). Marka Yönetimi ve Marka Değerinin Ölçülmesi (Cilt 1. Basım).isstanbul: Beta Basım,87. 